Review Article

www.ijrap.net

\title{
A CRITICAL ANALYSIS OF SLESHMA PAREEKSHA WITH SPECIAL REFERENCE TO SPUTUM TEST: A REVIEW \\ B M Rashmi $^{1}{ }^{*}$, Kumari Nisha ${ }^{2}$ \\ ${ }^{1}$ PG Scholar, Department of Roga Nidana, SDM College of Ayurveda and Hospital, B M Road, Thanniruhalla, Hassan, Karnataka, India \\ ${ }^{2}$ Associate Professor , Department of Roga Nidana, SDM College of Ayurveda and Hospital, B M Road, Thanniruhalla, Hassan, Karnataka, India
}

Received on: 12/07/16 Revised on: 01/08/16 Accepted on: 07/09/16

\author{
*Corresponding author \\ E-mail: drrashmibm@gmail.com
}

DOI: $10.7897 / 2277-4343.075185$

\begin{abstract}
The product that comes out after coughing is 'Nishtyuta'(sputum). It is the secretion of the lungs (Mala rupa kapha) which has become increased, which may contain some amount of Pooya (pus), Rakta (blood), Krimis (microbes) and even Puppusa mamsa (Lung Tissue) in many diseased conditions. It comes out after kasa (cough) easily if it is thin, but when it becomes thick it can be brought out after severe coughing. Examination of Sleshma (sputum) can be done through Roga Pareeksha (Disease Examination) by Darshana (inspection), Sparshana (palpation) and Prashna pareeksha (interrogation). In Ayurveda classics we find very few references regarding Sleshma pareeksha with special reference to Sputum. So this article mainly explains about both Ayurveda and Modern tools for the assessment of Sleshma (Sputum).
\end{abstract}

Keywords: Nishtyuta, sleshma, roga pareeksha, sputum.

\section{INTRODUCTION}

The product that comes out after coughing is Nishtyuta(sputum). It is the secretion of the lungs (mala rupa kapha) which has become increased, which may contain some amount of Pooya (pus), Rakta (blood) , Krimis (microbes) and even Puppusa mamsa (Lung Tissue) in many diseased conditions. It comes out after Kasa (cough) easily if it is thin, but when it becomes thick it can be brought out after severe coughing. We have a very few references regarding Sleshma Pareeksha in our classics which are scattered in various Sthanas. It can be understood through Roga pareeksha in Ayurveda and sputum examination in Contemporary context.

Saama Kapha Lakshanas: We can consider Sama Kapha Lakshanas as Sleshma pareeksha in Ayurveda ${ }^{1}$.

"aavilastantulaha styanaha kanthadeshe avatishtate | saamo balaaso durgandhihi kshududgara vighatakrut |"”

(Ash.Hru.Su.13/ 37-38)

There is increased turbidity of the kapha (phlegm) which is thready ,sticky, stagnates in throat, foul smell, complete loss of appetite and obstruct the eructations.

As 'Kapha' is mala of' Rasa dhatu' we can consider Sama Rasadhatu malaroopi kapha lakshana for examination of sleshma ${ }^{1}$. When rasadhatu malarupi kapha combines with aama produces these symptoms: (Cha.chi.18 chapter)

"Sa kapha"

"Sleshmana pittasamsrusta|"

"Bahulam madhuram snigdham nishteevati ghanam kapham|"

"Durdandhi hareetam raktam stheevet pooyopamam kapham|"

"Picchilam bahalam visram haritam shwetapeetakam| kaasamano rasam yakshmee nishteevati kaphaanugam||" 2(Cha.Chi.8/ 51)

"Saandra kapha|" ${ }^{3} \mid$ (su.sam.utt.52/10)
Ayurveda explains abnormalities in Sleshma (sputum) due to affliction of various doshas. It can be assessed by Roga Pareeksha - Trividha pareeksha (3 folds of Examination)Darshana (inspection), Sparshana (palpation) and Prashna pareeksha (interrogation) or through Pratyaksha (direct observation), Anumana (doubting) and Aptopadesha pramana (said by elders/ guru).

Using Pratyaksha Pramana (Direct Observation)

- Chakshurendriya (Eye): One has to look for Sleshma Pramana (quantity), appearance of sleshma and consistency of sleshma (sputum) .

- Ghranendriya (Nose): Have to look for odour of sleshma (sputum) .

- Sparshanendriya (Skin) : One has to look for temperature of sleshma (sputum) and consistency of sleshma.

Using Aptopadesha Pramana: 'Aptopadesha'- means Verbal or scriptural testimony, told by our Ayurveda Acharyas in Classics. Abnormal features of Sleshma (sputum) is due to affliction of various doshas (like vata, pitta and kapha). By using textual references, we can assess Sleshma (sputum).

Darshanendriya Pareeksha: It includes examination same as Chakshurendriya (through eye) pareeksha

Examples for appearance of Sleshma

1. Kshayaja Kasa: Harita, Rakta, Pooyopama (green, blood, associated with pus)

2. Kshataja kasa: Shushka kapha, sashonita (dry sputum, associated with blood)

3. Raktaja Pratishyaya (Rhinitis): Rakta srava (blood discharge)

4. Pittaja Kasa: Peeta nishteevata (yellow sputum) 
5. Pittaja Pratishyaya (Rhinitis): Sapeeta srava (yellow discharge)

Consistency of Sle shma (Sputum): Assessed as follows;

- Through Chakshurendriya pareeksha: sleshma can be assessed by using dropper. Aspirate the sleshma (sputum) into pipette $\&$ then allowing to drop by gravity \& observe.

- Through Sparshanendriya: Sleshma can be assessed by using Physician's hand checking for consistencies. Ex: Vataja Pratishyaya- Tanu srava (thin discharge) ; Kaphaja Kasa- Ghana Kapha (thick sputum).

Relation between various orifices and consistency of Sleshma (Sputum):

Based on the orifices involved and consistency, Sleshma can be classified into three types-

Nose: Here sleshma will be thin in consistency.
Throat: Here sleshma will be slightly thicker than nasal discharge.

Alveoli: Here sleshma will be considered thickest of all above secretions.

Assessment of temperature in sleshma: It is done through Sparshanendriya pareeksha (skin) using physicians hand. Ex: In Vataja Pratishyaya (Rhinitis of vata origin) - Ushna srava (warm/ hot discharge) and in Kaphaja Pratishyaya (Rhinitis of kapha origin) - Sheeta srava (cold discharge).

Assessment of odour in sleshma: Is done through Ghranendriya pareeksha (nose). Ex:1. Kshayaja Kasa (cough)Durgandha (bad smell). ${ }^{2}$. Raktaja Pratishyaya (Rhinitis)Durgandha (foul or bad smell).

Presentation of sleshma in various diseases

It can be understood with these few examples as follows;

Table 1: Assessment of sleshma in pratishyaya (rhinitis) ${ }^{4}$

\begin{tabular}{|c|c|c|c|c|}
\hline Features & Vataja & Pittaja & Kaphaja & Raktaja \\
\hline Color & - & Sapeeta (yellow) & Shukla (white) & Rakta (blood) \\
\hline Odour & - & - & - & Durgandha (bad smell) \\
\hline Temperature & - & Ushna(hot/warm) & Sheeta (cold) & Ushna (hot/warm) \\
\hline Consistency & Tanusrava(thin) & - & Sravet muhu (frequent discharge) & - \\
\hline
\end{tabular}

Table 2: Assessment of sleshma in kasa (cough) ${ }^{5}$

\begin{tabular}{|c|c|c|c|c|c|}
\hline Features & Vataja & Pittaja & Kaphaja & Kshataja & Kshayaja \\
\hline Color & - & $\begin{array}{c}\text { Peeta } \\
\text { (yellow) }\end{array}$ & - & - & $\begin{array}{c}\text { Harita,rakta,puya (green, } \\
\text { mixed with blood and pus) }\end{array}$ \\
\hline Temperature & - & - & - & - & Durgandha (foul smell) \\
\hline Odour & Cunsistency & Tanu (thin) & $\begin{array}{c}\text { Snigdha, Ghana,Sandra } \\
\text { (unctuous, thick ) }\end{array}$ & $\begin{array}{c}\text { Initially shushka (dry) later } \\
\text { expectorates blood }\end{array}$ & - \\
\hline Quantity & $\begin{array}{c}\text { Diminished } \\
\text { after } \\
\text { expectoration }\end{array}$ & - & Bahula (large) & - & - \\
\hline
\end{tabular}

Relation Between Varna, Jalanimajjana Pareeksha and Sadhyasadhyata (Prognosis)

We have scattered references regarding prognosis of patient based on varna (color), of sleshma and jala nimajjana pareeksha (Test based on sinking or floating in water) in Charaka Samhita- Indriya Sthana. Copious expectoration of sputum having blue, yellow or red color from the uras (chest), Physician should discard him from a distance. If sputum sinks in water when placed on it, he should be considered as moribund. If several colors appear in sputum of a person and if it sinks in water, he cannot survive $e^{6,7}$.

\section{Examination of the sputum (contemporary view)}

Examination of Sputum gives invaluable information in Respiratory diseases. This is mandatory in all cases where infections or neoplasia are suspected.

Introduction: Sputum is a mixture of bronchial secretions, cells and organisms which are discharged from the airways ${ }^{8}$. Normal sputum may be colourless and mucoid, it is loose and non-sticky in character. Most persons do not spit out sputum. The secretions pass up from the respiratory tract by ciliary action and cough, and are swallowed. Normal quantity does not exceed a few millilitres in 24 hours. If history of sputum is positive, then enquire for its amount, character, viscosity \& colour or taste.
Abnormalities of the sputum

Mucoid sputum: It is clear and viscous. In smokers it may be gray or black in colour. Is usually present in Chronic Bronchitis. It is more copious in the mornings.

Watery sputum: This is frothy, voluminous and often blood tinged and seen in Acute Pulmonary Oedema.

Sticky and Tenacious Sputum: Whenever infection complicates Chronic Bronchitis or there is exacerbation of Chronic Bronchial Asthma, sputum is presented in this way, which is difficulty to expectorate. Obstruction of the airways by thick secretions worsens the dyspnoea. Expectoration gives relief.

Purulent sputum: It resembles pus and it is yellow or greenish. Often it is large in amount and brought out easily with cough. It is a sign of infection seen in Bronchitis, Pneumonia, Lung abscess.

Rusty sputum: This is suggestive of Pneumococcal Pneumonia. It is due to admixture of altered blood with sputum. Sputum resembling red jelly results from mixture of mucous and blood and is sometimes seen in Bronchogenic Carcinoma.

Foul smelling sputum: It may be present when infection is caused by anaerobic bacteria. May be seen in Bronchiectasis, Lung abscess or Necrotising Pneumonia.

Reddish brown sputum: sputum resembling reddish brown or chocolate pus (anchovy sauce pus) is expectorated when Amoebic abscess in the Liver or Lung erodes into a bronchus. 
Sputum Examination: It can be discussed under four headings:

1. Collection of sputum

2. Inspection of sputum

3. Gram staining and

4. Microbiological Examination.

Collection of the sputum: A clean wide mouthed sterile bottle should be used for the sputum collection. Most patients find it easier to bring out sputum in the early morning soon after waking up. Sputum brought out from the lower respiratory tract should be collected without contamination by saliva. To assess the total daily output of the sputum it should be collected for 24 hours?.

Inspection: Note the colour, smell and quantity of sputum sample. It is viscid and yellow in acute bronchitis, bronchiectasis and lung abscess. It is white and mucoid in chronic bronchitis, Bronchial asthma and Pulmonary tuberculosis. Rusty sputum is suggestive of pneumonia. Presence of Curschmann's spirals which are bronchial casts suggests Bronchial Asthma and allergic Bronchopulmonary Aspergillosis. Watery and blood stained sputum suggests pulmonary oedema. Chocolate colour sputum may suggests Amoebiasis. Intense foul smell should suggest chronic suppuration as in Bronchiectasis and Lung Abscess.

Contents of sputum in bronchial asthma: Crusch mann's spirals, Eosinophils, Charcot Leyden crystals and Bronchial Epithelial Cells.

Three Layer Test: Allow the sputum to stand in a conical glass. In conditions such as Bronchiectasis and Lung abscess, it may form 3 distinct layers -thick purulent sputum below, serus fluid in the middle and froth above.

Microscopy: Normally there may be epithelial cells, leucocytes, fibrinous strands and bacteria. Abnormal contents include large number of epithelial cells, pus cells, elastic fibres, malignant cells, curschmann's spirals, charcot Leyden crystals, fibrinous casts and parasites.

Gram's Stain: This is done to visualise gram positive and gram negative bacteria ${ }^{10}$.

Procedure: Make a smear of sputum and fix it by heating over a flame. Pour gentian violet over it for 3 minutes to stain. Pour gram's iodine over it for 1 minute for mordanting action. Drain off, wash and decolourize with alcohol. Wash with water. Pour safranin for 30 seconds for counter staining. Wash and dry the slide and mount under the oil immersion.

Ziehl Neelsen's Stain: This is done to visualise Acid-fast bacillus (AFB) e.g. Mycobacterium tuberculosis and Mycobacterium leprae.

Procedure: Make a smear of sputum and fix it by heating over a flame. Pour Carbol Fuschin over the smear and heat it from below (till fumes rise) for 5 minutes, taking care not to char the smear and later wash with water. Decolourise with $20 \% \mathrm{H} 2 \mathrm{SO} 4$ (5\% H2SO4 is used for M. leprae) Wash and counter stain with Loffler's Methylene Blue for 1 minute. Wash and dry the slide and mount under oil immersion.

\section{Papanicolaou Stain}

It is done to study the cytological abnormalities in sputum, detect and identify malignant cells and demonstrate the nature of bronchial casts.

Fluoresent Microscopy: It is useful when large number of sputum specimen have to be examined for Tubercle bacilli. It is much more sensitive than acid-fast staining, but it requires special staining methods and fluorescent microscope. The equipment is very costly and it demands special skill for proper use. Though it is very expensive, it is useful when Ziehl-Neelsen staining is negative.

Microbiological Examination: This consists of culture of the sputum and tests for drug sensitivity. For reliable results the sputum should be free from contamination by organisms from the mouth and upper respiratory tract.

Equipments required for preparing sputum smear: Bunsen burner, Sputum sample in a container, Sterile cotton swabs, Glass slides, Pencil / Marker.

Procedure for sputum smear preparation: Use a sterile cotton swab to extract the specimen from the container. The sample to be used may be drawn up the side of the container with the swab to make selection easier. Mucus can be "cut" with the swab by drawing the swab against the side of the container and thus separating off part of the mucus. Merely dipping the swab into the specimen will not usually provide the best sample. Place the sample on one of the labeled slides. The sample may be transferred from the swab to the slide by a gentle rolling motion of the swab on the slide. Fix the smear by passing it through a Bunsen flame several times. Then stain the sample with general gram staining techniques. Stand the smear in a slide rack and allow the smear to air dry thoroughly. Then microscopic examination of the sputum is done under $100 \mathrm{X}$ Oil immersion objective.

Elements present in the sputum: It can be classified into two;

1. Cellular elements: Squamous epithelial cells, respiratory epithelial cells, Polymorph nuclear leukocytes and alveolar macrophages.

2. Non-Cellular elements: Mucus thread, Curschmann's spirals, Bacteria and Yeast.

\section{DISCUSSION}

Sputum is not sterile, so when a person has an infection, there will typically be pathogenic bacteria present. Specific techniques are carried out to identify such bacteria then antimicrobial susceptibility testing is usually performed so that the appropriate antibiotics can be prescribed.

\section{CONCLUSION}

There are very few references regarding Sleshma pareeksha in our classics, which are scattered in various sthanas of Samhitas. It is considered to occur because of Pranavaha sroto dushti which is due to various nidana sevana. Indriya sthana of Charaka samhita, emphasize on prognosis of patients based on physical appearance of nishtyuta. Saama kapha lakshanas mentioned in classics, can be considered as an important tool for sleshma pareeksha .Early the diagnosis, better will be the prognosis. There is a need for conducting various research on sleshma pareeksha for its better understanding through Ayurveda.

\section{REFERENCES}

1. PS Byadgi, Parameshwarappa's Vikruti Vijnana, Volume 1, Chapter 9, Ama, Chaukamba Samskrit Samsthan, New Delhi, 1st Edition, 2007, p.199,204.

2. Acharya YT, Charaka Samhitha by Agnivesha with Acharya Chakrapani Dutta Commentry, Chikitsa Sthana, 
Rajayakshma Chikitsa Adhyaya, Chapter- 8, Verse:51, Chaukamba Publication, Varanasi, p.461.

3. Acharya YT, Reprint 2013, Sushrutha Samhitha by Achaya Sushrutha, Uttara Sthana, Shwasa Pratishedha Adhyaya, Chapter 52, Verse:10, Chaukamba Publication, New Delhi, p. 762

4. Acharya Sushrutha, Uttara Sthana, Pratishyaya Pratishedha Adhyaya, Chapter 24, Chaukamba Publication, New Delhi, p.651-52.

5. Acharya YT, Charaka Samhitha by Agnivesha with Acharya Chakrapani Dutta Commentry, Chikitsa Sthana, Kasa Chikitsa Adhyaya, Chapter 18, Verse:48-50,

6. Chaukamba Publication, Varanasi, p.540-541.

7. Acharya YT, Charaka Samhitha by Agnivesha with Acharya Chakrapani Dutta Commentry, Indriya Sthana, Katamanishirasiya Indriya, Chapter- 6, Verse:15, Chaukamba Publication, Varanasi, p.461.

8. Acharya YT, Charaka Samhitha by Agnivesha with Acharya Chakrapani Dutta Commentry, Indriya Sthana, Yasyashyavanimittiyamindriyam, Chapter 9, Verse:18-19, Chaukamba Publication, Varanasi, p.368.
9. KV Krishna Das Editor, 4th Edition, Clinical Medicine( A Textbook of Clinical Methods and Laboratory Investigations), Chapter 12, Examination of the Respiratory System, Jaypee Publication, 2013, p.121, 141, 147.

10. Godkar B Praful, Textbook Of Medical Laboratory Technology, Routine Examination of Sputum, Chapter 46, Bhalani Publication, Mumbai, Reprint 2011,p.390-91; 61213.

11. BS Nagoba, 2nd Edition, Medical Microbiology, Pre Manual For Undergraduates, Microscopy and Staining Techniques, Chapter 3, Elsevier Publications, India, Reprinted 2014, p. 14-15.

\section{Cite this article as:}

B M Rashmi, Kumari Nisha. A critical analysis of sleshma pareeksha with special reference to sputum test: A review. Int. J. Res. Ayurveda Pharm. Sep - Oct 2016;7(5):8-11 http://dx.doi.org/10.7897/2277-4343.075185

\section{Source of support: Nil, Conflict of interest: None Declared}

Disclaimer: IJRAP is solely owned by Moksha Publishing House - A non-profit publishing house, dedicated to publish quality research, while every effort has been taken to verify the accuracy of the content published in our Journal. IJRAP cannot accept any responsibility or liability for the site content and articles published. The views expressed in articles by our contributing authors are not necessarily those of IJRAP editor or editorial board members. 